\title{
Calliphorid fly (Diptera, Calliphoridae) attraction to different colored traps in the Tingua Biological Reserve, Rio de Janeiro, Brazil
}

\author{
Renata S. Mello ${ }^{1,2}$, Margareth M. C. Queiroz ${ }^{2}$, André F. Nunes-Freitas ${ }^{3}$ \& Valéria M. Aguiar-Coelho ${ }^{4}$
}

1. Programa de Pós-Graduação em Biologia Animal, Instituto de Biologia, Universidade Federal Rural do Rio de Janeiro (UFRRJ), Rodovia BR 465, Km7, 23890-000 Seropédica, RJ, Brazil. (mellorebio@yahoo.com.br)

2. Laboratório de Transmissores de Leishmaniose, Setor de Entomologia Médica e Forense, IOC/ FIOCRUZ, Avenida Brasil, 4365 , Manguinhos, 21045-900 Rio de Janeiro,RJ, Brazil. (rsmello@ioc.fiocruz.br; mmcqueiroz@ioc.fiocruz.br)

3. Laboratório de Ecologia Florestal e Biologia Vegetal, Departamento de Ciências Ambientais/IF, Universidade Federal Rural do Rio de Janeiro, Rodovia BR 465, Km7, 23890-000 Seropédica, RJ, Brazil. (afnfreitas@ufrrj.br)

4. Laboratório de Estudo de Dípteros, Departamento de Microbiologia e Parasitologia. Universidade Federal do Estado do Rio de Janeiro, Rua Frei Caneca 94, Centro, 20211-040 Rio de Janeiro, RJ, Brazil. (valeria@unirio.br)

\begin{abstract}
The present study intended to analyze calliphorid attraction to traps painted in a variety of colors and the calliphorid constancy index in the Tingua Biological Reserve, Rio de Janeiro state, Brazil. The Diptera were collected monthly in the Reserve, between 2002 and 2005, totaling 24 samplings. Four traps containing sardines as bait were painted olive green, blood red, black, or white and exposed for $48 \mathrm{~h}$ at four equidistant points, $50 \mathrm{~m}$ from each other. To determine the calliphorid species constancy, the Bodenheirmer constancy index was used throughout the study. To analyze differences in the total abundance between species and in their color selection, an ANCOVA test with a significance level of $5 \%$ and a Tukey post-test were used, considering the categories species and color as cofactors and climatic variables as co-variables (temperature, relative humidity and precipitation), since the samples were collected over two years. 10,444 insects were captured. Of these, $56 \%$ belonged to the Calliphoridae family, totaling 13 species, with the most frequent species being Laneela nigripes (28.5\%), Hemilucilia semidiaphana (17\%), and Mesembrinella sp. (16.4\%). The other species had frequencies lower than $12 \%$. Nine species were considered constant, two accessories, and two accidental. The data indicated that the most frequent species presented significant differences between themselves concerning abundance over the captured months, however, the Tukey post-test indicated differences only between a few of them. The black trap presented the higher relative calliphorid frequency $(27.34 \%)$, followed by green $(25 \%)$, red $(24.0 \%)$, and white $(23.7 \%)$, although the species abundance in the different colored traps did not differ significantly among themselves. Therefore, there was no Calliphorid flies preference for any of the tested colors.
\end{abstract}

KEYWORDS. Alternative control, behavior, blowflies, colored traps.

RESUMO. Atração de califorídeos (Diptera, Calliphoridae) por diferentes cores de armadilhas na Reserva Biológica do Tinguá, Rio de Janeiro, Brasil. O presente estudo teve como objetivo analisar a atração de califorídeos por armadilhas pintadas com diferentes cores de tinta e calcular o índice de constância destas moscas na Reserva Biológica do Tinguá, Rio de Janeiro. Os dípteros foram coletados mensalmente na Reserva entre 2002 e 2005, totalizando 24 amostras. Quatro armadilhas contendo sardinha como isca foram pintadas com tinta nas cores verde (oliva), vermelho (sangue), preto e branco e foram expostas por $48 \mathrm{~h}$ em quatro pontos equidistantes distanciadas 50 metros entre si. Para determinar a constância das espécies de califorídeos, o índice de constância Bodenheirmer foi utilizado. E para analisar as diferenças nas abundâncias totais entre as espécies e a seleção de cor por elas, foi utilizado um teste de análise de co-variância (ANCOVA) com nível de significância de $5 \%$ e pós-teste Tukey, considerando as categorias espécies e cor como cofatores e as variáveis ambientais como co-variáveis já que as coletas foram ao longo de dois anos. Foram capturados 10.444 insetos. Destes, $56 \%$ pertencentes à família Calliphoridae, em um total de 13 espécies, sendo as mais frequentes Laneela nigripes (28,5\%), Hemilucilia semidiaphana (17\%), e Mesembrinella sp. (16,4\%). As outras espécies coletadas tiveram frequência inferior a $12 \%$. Nove espécies de califorídeos foram consideradas constantes, duas acessórias e duas acidentais. Os dados indicaram que as espécies mais constantes apresentaram diferenças significativas nas suas abundâncias ao longo dos meses de captura, no entanto, o pós-teste Tukey indicou diferenças somente entre algumas. A armadilha preta apresentou a maior frequiência relativa $(27,34 \%)$, seguida pela verde $(25 \%)$, vermelha $(24 \%)$ e branca $(23,7 \%)$, embora a abundância das espécies entre as diferentes cores não tenha diferenciado entre si. Desta forma não houve preferência dos califorídeos por nenhuma das cores testadas.

PALAVRAS-CHAVE. Armadilhas coloridas, califorídeos, comportamento, controle alternativo.

Calliphorids play a crucial role in the maintenance and balance of land ecosystems, especially due to the feeding habits of their larvae. The larvae inhabit substances and organic waste produced by human and animal activities, especially feces and plant residues (MonteIro, 1995). The larvae are detritivorous and aid in the decomposition of organic materials. In addition, a large number of calliphorid species serve as potential forensic indicators, useful in estimations of postmortem intervals (PMI), constituting an additional tool for medical and criminal investigations (GREENBERG, 1991; CatTs \& Goff, 1992; Moura et al., 1997).

Calliphorids are also responsible for great damages in agropecuary through traumatic myiasis that they cause in domestic and wild animals, and even in man (ZUMPT, 1965; Guimarẽes et al., 1983; MoYa-BorJa, 2003; SuKONTASON et al., 2005). Some calliphorid species can also act as phoretic hosts of Dermatobia hominis (Linnaeus Jr., 1781) (Oestridae) eggs, the cause of furunculous myiasis (MARINHO et al., 2003). In addition, these insects are responsible for the transmission of a series of etiological agents, including fungi, helminth eggs and larvae, protozoan cysts, and enterovirus, both to man and other animals (FurLANETTO et al., 1984; OLIVEIRA et al., 2002).

Due to the medical/veterinary and sanitary problems caused by these Diptera, several studies have been conducted with the purpose of developing effective 
measures for the control and reduction of these insect populations (KIRK, 1984; GREEN \& W ARNES, 1992; PICKENS et al., 1994; Cilek, 2002; Мinok, 2002; FraGa \& D'Almeida, 2005). Since flies have the ability to distinguish colors and polarized light (PICHAUD et al., 1999), the capture of these insects can be simple and optimized with the use of appropriately colored traps (Prokopy \& Owens, 1978). Accordingly, size, shape, odor, and trap color have been taken into consideration (NDEGWA \& MiноK, 1999), with the purpose of developing traps with a high attractiveness and capture potential to muscoid Diptera.

Then, this study attempted to analyze calliphorid attraction to different colored traps as well as to test the constancy of these Diptera during the captures months in the Tingua Biological Reserve, State of Rio de Janeiro, Brazil. As a hypothesis that different colors traps can influence the capture of calliphorid flies and that in ombrophilous forest will be found assynanthropic species as constants and syannthropic species as accessory or accidental.

\section{MATERIAL AND METHODS}

The study was conducted in the Tingua Biological Reserve (ReBio-Tingua) (S 22 $28^{\circ}-2^{\circ} 39^{\prime}$; W 43 ${ }^{\circ} 13^{\prime}$ $\left.43^{\circ} 34^{\prime}\right)$, located approximately $70 \mathrm{~km}$ from the city of Rio de Janeiro, at the northern limit of the "Baixada Fluminense" area within the mountainous area of the state. The majority of the ReBio-Tingua is located in the municipalities of Nova Iguaçu and Duque de Caxias, the "Baixada Fluminense" area, but also extends into the municipalities of Petropolis and Miguel Pereira, the mountainous area (MARINHO et al., 2006). It ranges over an area of 26,206 ha and is covered in dense ombrophilous forest at different stages of regeneration. It is considered the highest concentration of primary Atlantic Rainforest in the Rio de Janeiro State (Rocha et al., 2003). The climate is tropical humid, with temperatures ranging between 15.7 and $27.7^{\circ} \mathrm{C}$ (MARINHO et al., 2006).

To test possible color preferences in the efficiency of trap sampling, four traps according to Mello et al. (2007) were painted with green, red, black, or white paint. The traps were baited with sardines that had been allowed to defreeze in the refrigerator $24 \mathrm{~h}$ before in the field and were left in the study area for $48 \mathrm{~h}$. In the field, the traps were set $1.5 \mathrm{~m}$ above the soil at four distinct points, equidistant between themselves at approximately $50 \mathrm{~m}$, on a trail in the ReBio-Tingua area about $200 \mathrm{~m}$ from the administrative headquarters. A total of 24 samplings were conducted between June 2002 and January 2005. At each sampling, the traps were alternated between the four sampling points, to avoid bias associated with the microclimatic conditions at each point.

The insects were sacrificed with ether and preserved in $70 \%$ ethanol, with members of the Calliphoridae family identified at the species level using the taxonomic key described by Mello (2003). The specimens were deposited in the entomological collection at the Oswaldo Cruz Institute (IOC/FIOCRUZ), Rio de Janeiro, Brazil.
The abundance and relative frequencies of the captured calliphorid species were calculated in each differently colored trap. To determine if the analyzed calliphorid species were constant during the study, in other words, captured during every month, the Bodenheirmer constancy index was used (SilveiRa-Neto et al., 1976): $C I=\frac{p \times 100}{n}$, where $C I=$ Constance of species, $p=$ number of samplings containing the studied species; $n=$ total number of conducted samplings. According to the results, the following categories were defined: con - constant species $=$ present in over $50 \%$ of samplings; acce - accessory species $=$ present in $25-50 \%$ of sampling; and acci - accidental species = present in less than $25 \%$ of samplings.

Comparisons of total abundances of different species and color selection by different calliphorid species were analyzed by covariance analysis (ANCOVA), considering the categories species and color as co-factors and climatic variables as co-variables (temperature, relative humidity and precipitation), since the samples were collected over a 24-month period (ZAR, 1999). The data were transformed in $\log (\mathrm{x}+1)$ to obtain homogeneity of variance. Since the month of December 2002 was considered an outlier for some species, it was excluded from the analysis.

\section{RESULTS}

A total of 10,444 muscoid Diptera were sampled, with $56 \%(\mathrm{~N}=5,609)$ belonging to the Calliphoridae family, and comprising a total of 13 species, the three most frequently collected species were Laneela nigripes (Guimarães, 1977) (28.5\%), Hemilucilia semidiaphana (Rondani, 1850) (17\%) and Mesembrinella sp. (16.4\%) (Tab. I). The other species exhibited frequencies lower than $12 \%$ when analyzed individually and, when summed up, totaled $38.1 \%$ of the total sampled calliphorid number (Tab. I). From the 13 species of calliphorids, nine (69.2\%) were considered constant, two accessory, and two accidental (15.4\% for both categories) (Tab. I). For the other analyses, only those species that had total abundances higher than 100 individuals $(n=8$ species $)$ and $\mathrm{CI}>50 \%$ were used.

The data indicated that the eight most frequent species had significant differences in their total abundances (ANCOVA: $\mathrm{df}=7 ; \mathrm{F}=18.439 ; \mathrm{p}<0.01$ ). However, the Tukey test indicated significant differences only between some of the species (Tab. I). The trap that had the highest capture values was black $(27.3 \%)$, followed by green ( $25.0 \%)$, red (24.0\%), and white (23.7 $\%)$. However, the ANCOVA test did not indicate significant differences in calliphorid abundance between the different traps (ANCOVA: $\mathrm{df}=3 ; \mathrm{F}=0.215 ; \mathrm{p}=0.886$ ).

None of the eight calliphorid species exhibited significant differences in selecting traps by color $(p>$ $0.05)$. When the variables of species and color were analyzed simultaneously as co-factors, only the species category explained an additional fraction of the abundances (ANCOVA: $\mathrm{df}=7 ; \mathrm{F}=18.439 ; \mathrm{p}<0.001$ ), while color did not $(\mathrm{p}=0.886)$. 
Table I. Constancy index (CI), absolute (n) and relative frequency (\%) of the captured calliphorid species in different traps, between July 2002 and January 2005 in the Tingua Biological Reserve, Rio de Janeiro, Brazil. Different letters indicate significant differences in the total abundance values between the calliphorid species with a sampling of over 100 individuals (con, constant species $=$ present in over $50 \%$ of samplings; acce, accessory species $=$ present in $25-50 \%$ of sampling; acci, accidental species $=$ present in less than $25 \%$ of samplings).

\begin{tabular}{|c|c|c|c|c|c|c|c|c|c|c|c|}
\hline \multirow{3}{*}{ Species } & \multicolumn{9}{|c|}{ Colored traps } & & \\
\hline & \multicolumn{3}{|c|}{ Green } & \multicolumn{2}{|c|}{ Red } & \multicolumn{2}{|c|}{ Black } & \multicolumn{2}{|c|}{ White } & \multicolumn{2}{|c|}{ Total } \\
\hline & CI $(\%)$ & $\mathrm{n}$ & $\mathrm{F}(\%)$ & $\mathrm{n}$ & $\mathrm{F}(\%)$ & $\mathrm{n}$ & $\mathrm{F}(\%)$ & $\mathrm{n}$ & $\mathrm{F}(\%)$ & $\mathrm{n}$ & $\mathrm{F}(\%)$ \\
\hline Laneela nigripes & $100(\mathrm{con})$ & 339 & 21.2 & 384 & 24.2 & 422 & 26.4 & 451 & 28.2 & $1596^{\mathrm{a}}$ & 28.5 \\
\hline Hemilucilia semidiaphana & 87 (con) & 193 & 20.3 & 256 & 27.0 & 338 & 35.6 & 162 & 17.1 & $949^{\mathrm{c}}$ & 17.0 \\
\hline Mesembrinella sp. & 100 (con) & 237 & 25.7 & 173 & 18.8 & 248 & 26.9 & 264 & 28.6 & $922^{\mathrm{c}}$ & 16.4 \\
\hline Lucilia eximia & 96 (con) & 214 & 33.8 & 155 & 24.5 & 140 & 22.1 & 124 & 19.6 & $633^{\mathrm{b}, \mathrm{c}}$ & 11.3 \\
\hline Chrysomya albiceps & 71 (con) & 141 & 24.1 & 119 & 20.4 & 167 & 28.5 & 157 & 28.8 & $584^{\mathrm{c}}$ & 10.4 \\
\hline Hemilucilia segmentaria & 71 (con) & 113 & 38.6 & 62 & 21.2 & 69 & 23.5 & 49 & 16.7 & $293^{\mathrm{b}}$ & 5.2 \\
\hline Chloroprocta idioidea & 75 (con) & 76 & 29.2 & 93 & 35.8 & 52 & 20.0 & 39 & 15.0 & $260^{\mathrm{b}}$ & 4.6 \\
\hline Chrysomya megacephala & 54 (con) & 48 & 27.3 & 41 & 23.3 & 45 & 25.6 & 42 & 23.8 & $176^{\mathrm{b}}$ & 3.1 \\
\hline Chrysomya putoria & 21 (acci) & 13 & 17.1 & 43 & 56.6 & 9 & 11.8 & 11 & 14.5 & 76 & 1.4 \\
\hline Cochliomyia macellaria & 42 (acce) & 15 & 30.6 & 13 & 26.5 & 10 & 20.4 & 11 & 22.4 & 49 & 0.9 \\
\hline Eumesembrinella pauciseta & 50 (acce) & 11 & 29.7 & 7 & 18.9 & 16 & 43.2 & 3 & 8.1 & 37 & 0.6 \\
\hline Lucilia cuprina & 96 (con) & 1 & 3.8 & 1 & 3.8 & 18 & 69.2 & 6 & 23.1 & 26 & 0.5 \\
\hline Paralucilia pseudolyrcea & 8 (acci) & 0 & 0 & 0 & 0 & 0 & 0 & 8 & 100 & 8 & 0.1 \\
\hline Total & & 1,401 & 25.0 & 1,347 & 24.01 & 1,534 & 27.34 & 1,327 & 23.65 & 5,609 & 100 \\
\hline
\end{tabular}

\section{DISCUSSION}

The results of this study show that the three most frequent species (L. nigripes, $H$. semidiaphana and Mesembrinella sp.) were responsible for over $60 \%$ of the total calliphorid number sampled, in addition to being constant species throughout the year. Laneela nigripes $(28.5 \%)$ and Mesembrinella sp. $(16.4 \%)$ had the highest sampling dominance, with $100 \%$ constancy. The second most captured species was $H$. semidiaphana (17\%), and similar results were observed by MARINHO et al. (2006) in another area of the ReBio-Tingua. This last species had a constancy of $87 \%$, while the Hemilucilia segmentaria (Fabricius, 1805) constancy was $71 \%$. These species are considered assynanthropic, in other words, restricted to forest environments and adverse to anthropized environments (Mello, 1967; D’Almeida \& LoPes, 1983). The high constancy is consistent with other authors' results (Mello, 1967; D’Almeida \& LoPES, 1983; Ferreira \& BARBOLA, 1998; PARALlupi \& CASTELlÓN, 1994), which classify this species as typically forest-dwelling. Therefore, these species can serve as environmental quality indicators, indicating that the ReBio-Tingua can be considered a high-quality conservation area.

On the other hand, the exotic genus Chrysomya (Robineau-Desvoidy, 1830), originally from Africa and introduced to Brazil in the 1970s (GUIMARÃEs et al., 1978; GUIMARÃEs et al., 1979), is composed primarily of synanthropic species (more present in urban areas), such as Chrysomya megacephala (Fabricius, 1794), Chrysomya albiceps (Wiedemann, 1819) and Chrysomya putoria (Wiedemann, 1830). These species were constant in the samplings, with the exception of $C$. putoria, which was considered an accidental species, thus the partial hypothesis that consider only assynanthropic species as constant in ombrophilous forest was refuted.

Although these species were classified as constant, few individuals were captured in each sampling, with the exception of the month of December 2002, which was excluded from the analysis for being an outlier. The fourth most abundant species, Lucilia eximia (Wiedemann, 1819), had a sampling constancy of $96 \%$. This species is typical in Neotropical and Neoarctic areas and is present in most rural and urban area census studies (PRADO \& GuimarÃEs, 1982; D’Almeida \& LoPES, 1983; MADEIRA $e t$ al., 1989; PARAlupPi \& CASTellón, 1994; Ferreira \& BARBOLA, 1998; MARINHO et al., 2003).

The presence of this species, with a high constancy index, as well as the presence of the Chrysomya genus in an environmental protection area can be considered an indication of anthropic disturbance (MELLO et al., 2007); at least in the months the samplings at ReBio-Tingua were conducted. Since the sampled area is located near the park headquarters and is near residential areas where garbage accumulates, the presence of these synanthropic species could indicate a high adaptation, colonization, and dispersion ability in forest areas, as described by PARALUPPI \& CASTELLÓN (1994).

The obtained results do not indicate significant differences in color selection by the analyzed calliphorid species, considering both the community and independent species; this was corroborated by the covariance analysis. HALL (1995) suggested that color is a secondary factor in calliphorid attraction, since these insects are attracted primarily by substrate odour. Therefore, it is probable that the calliphorid sampled in this study were attracted by the bait and that colored traps did not exert any additional attractiveness and/or exerted only secondary roles in the sampling, which was not reflected in the statistical analysis.

In general, blowflies tend to select dark colors, such as browns and purples, usually found in animal feces and decomposing bodies, which serve as substrates for oviposition (SILVA et al., 2001). Although our data did not indicate significant differences in Diptera abundance between the different colored traps, the trap with the 
highest calliphorid frequency was black. Since black is the color that least reflects light and, consequently, absorbs more heat (CASTRO et al., 2003), the use of traps of this color possibly accelerates the bait deterioration process and, therefore, is probably more attractive for muscoid Diptera.

Some authors suggest that myiasis-causing species in the zoophilic phase exhibit similar behavior to hematophagous Diptera, which are attracted to blackened objects (Hall, 1995; Green \& Warnes, 1992). In the present study, only Lucilia cuprina (Wiedemann, 1830) and Eumesembrinella pauciseta (Aldrich, 1922) exhibited behavior similar to hematophagous species, corroborating the authors' data, even though the latter species is not described as a myiasis-causing species in the literature. On the other hand, Cochliomyia macellaria (Fabricius, 1775), which causes secondary myiasis in humans, preferred green and red, exhibiting only a $20.4 \%$ frequency in the black colored trap.

Pickens (1994) observed that there was no significant difference in the abundance of $C$. megacephala between the different colored traps that were tested, although these authors reported a higher frequency of $C$. megacephala in the black colored trap. In this study, the highest frequencies were observed in the green traps, followed by the black. FRAGA \& D'AlMEIDA (2005) also observed that green and black colored traps were the most visited, and white was the least attractive for the capture of C. megacephala. However, these last authors did not conduct statistical tests to verify possible differences. It is noteworthy that C. megacephala was recently included as a myiasiscausing species for humans (SUKONTASSON et al., 2005). Therefore, an observation can made that the preferences of species that cause myiasis in humans to select dark colors is not very clear.

Ferraz \& Aguiar-Coelho (2008) tested three methodologies in laboratory for evaluate the attractiveness of $C$. megacephala to different colors (red, green, black, white, blue and yellow) using arena, fan and rectangle-shaped devices. In the first model, the attractiveness differed only in the second (green $>$ red) and the third landing (red was more attractiveness than green and black). Regarding to sex, the male was more attracted by black color and the female by red color. In the fan model, a few individuals were attracted by colored tubes, the male were more attracted to green followed by yellow and blue colors and female were attracted to same colors (green, yellow and blue) with similar frequencies among them. Using the rectangle-shaped devices, there was not differences in the landing among the colors used. Thus, it was observed that results were contradictory, then can say that this species not presents pattern for the color preference.

FRAGA \& D' AlmeIDA (2005) observed that L. eximia was found more frequently in green and red colored traps instead of other colors, a result verified in the present study. On the other hand, L. cuprina, even though it did not have a high capture rate in this study, was more frequently found in black and white traps. LEE (1937) observed that $L$. cuprina was more frequent in yellow traps; however, the colors this author used were different from the ones in the present study. Hall (1995) also observed the preferential attraction of L. cuprina to the color yellow, and observed similar behavior by phytophagous species that are preferably attracted to this color. On the other hand, FuKUSHI (1989) observed that the more attractive trap colors for this species were blue and yellow, with red and black being the least attractive colors.

Wall \& SMith (1996) studied the color discrimination by the sheep blowfly Lucilia sericata (Meigen, 1826). In the laboratory tested the colors: yellow, green, dark blue, red and light blue. In the field trials tested the colors: black, white, red and yellow, for each colored target it was used two distinct types of odour bait (chemical mixture "swormlure-4"; and liver and 10\% sodium sulphide solution). These authors observed in the laboratory that yellow sticky cloth targets caught the largest number both males and females, followed by light blue, black, green, dark blue and red. In the field, the authors observed an evident significant difference in the number of $L$. sericata caught between the two types of odour bait, although there was not observed the effect of color on catch. The authors suggested that the significant differences in catch depending on whether targets were in exposed or shaded positions, and those differences in the number of $L$. sericata caught by different target colors could be distinguished at sites exposed in full sunlight.

Even though some studies, such as the ones already discussed, demonstrate that certain trap colors present higher calliphorid visiting frequency, the data from the present study indicates that there is no significant preference for any of the tested trap colors, thus the initial hypothesis was rejected. However, other extrinsic factors (e.g. type of bait, luminosity, wind direction, and temperature), as observed by FraGa \& D' ALMEIDA (2005) and/ or wavelengths of incident light reaching the targets through the vegetation, perhaps most critically, contrast with the background as observed by WALL \& SMITH (1996), are likely to be able to modify responses to hue. In addition, factors intrinsic to the species as nutritional and physiological state and sex (HALL, 1995), also could exert influences on the effectiveness of trap capture. Therefore, additional studies are necessary to isolate the color factor in the attraction of muscoid Diptera.

The calliphorid species attraction to a particularly colored trap possibly will contribute to the control of muscoid Diptera of medical/veterinary and public health importance, allowing for traps with higher capture power, especially when combined with insecticides and synthetic pheromones.

Acknowledgments. The authors gratefully acknowledge IBAMA for granting permission for this research in the biological Reserve of Tingua, RJ and to the management of the biological Reserve of Tingua for its cooperation; the Universidade Federal do Estado do Rio de Janeiro (UNIRIO) and FINEP for financial support. M.Sc. Leandro S. Barbosa for his help in the taxonomic identification and collection of the specimens. M.Sc. Rafaela Dias Antonini and the M.Sc Leandro Talione Sabagh for their valuable suggestions in the manuscript. 


\section{REFERENCES}

Castro, A. P. A. S.; Labaki, L. C.; Caram, R. M.; Basso, A. \& Fernandes, M. R. 2003. Medidas de refletância de cores de tintas através de análise espectral. Ambiente Construído 3(2):69-76

Catts, E. P. \& Goff, M. L. 1992. Forensic Entomology in criminal investigations. Annual Review of Entomology 37:253-272.

CiLeK, J. E. 2002. Attractiveness of beach ball decoys to adult Stomoxys calcitrans (Diptera: Muscidae). Journal of Medical Entomology 39:127-129.

D'Almeida, J. M. \& Lopes, H. S. 1983. Sinantropia de dípteros caliptrados (Calliphoridae) no Estado do Rio de Janeiro. Arquivo da Universidade Federal do Rio de Janeiro 6:39-48.

Ferraz, A. C. P. \& Aguiar-Coelho, V. M. 2008. Desenvolvimento e avaliação de novas metodologias para testar a atratividade de Chrysomya megacephala (Fabricius) (Diptera: Calliphoridae) a estímulo visual por cores em Condições laboratoriais. Neotropical Entomology 37(3):334-337.

Ferreira, M. J. M. \& Barbola, I. F. 1998. Sinantropia de califorídeos (Insecta, Diptera) de Curitiba, Paraná, Brasil. Revista Brasileira de Biologia 58:203-209.

FraGa, M. B. \& D'Almeida, J. M. 2005. Observações preliminares sobre a atratividade por diferentes cores em Calliphoridae (Diptera), Niterói, RJ, Brasil. Entomologia y Vectores 12(1): 141-147.

FuKUsHI, T. 1989. Learning and discrimination of coloured papers in the walking blowfly, Lucilia cuprina. American Journal of Physiology 166:57-64.

Furlanetto, S. M. P.; Campos, M. L. C.; Harsi, C. M.; Buralli, G. M. \& Ishinata, G. K. 1984. Microorganismos enterepatogênicos em moscas africanas pertencentes ao gênero Chrysomya (Diptera: Calliphoridae) no Brasil. Revista de Microbiologia 15(3): $170-174$

Green, C. H. \& Warnes, M. L. 1992. Responses of female New World screwworm flies, Cochliomyia hominivorax, to coloured targets in the laboratory. Medical and Veterinary Entomology 6:103-109.

Greenberg, B. 1991. Flies as Forensic Indicators. Journal of Medical Entomology 28(5):565-577.

Guimarães, J. H.; Papavero, N. \& Prado, A. 1983. As miíases na região neotropical (identificação, biologia, bibliografia). Revista Brasileira de Zoologia 1(4):239-416.

Guimarães, J. H.; Prado, A. P. \& Buralli, G. M. 1979. Dispersal and distribuition of three newly introduced species of Chrysomya Robineau-Desvoidy in Brazil (Diptera, Calliphoridae). Revista Brasileira de Entomologia 23(4):245-255

Guimarães, J. H.; Prado, A. P. \& Linhares, A. X. 1978. Three newly introduced blowfly species in southern Brazil (Diptera: Calliphoridae). Revista Brasileira de Entomologia 22(1):53-60.

Hall, M. J. R. 1995. Trapping the flies that cause myiasis: their responses to host stimuli. Annals of Tropical Medicine and Parasitology 89(4):333-357.

KIRK, W. D. J. 1984. Ecologically selective coloured traps. Ecological Entomology 9:35-41.

LeE, D. J. 1937. A note on the Colour Responses of Lucilia cuprina. Council for Science Industrial Reserach 10:275-276.

Madeira, N. G.; Silveira, G. A. R. \& Pavan, C. 1989. The occorrence of primary in cats caused by Phaenicia eximia (Diptera: Calliphoridae). Memórias do Instituto Oswaldo Cruz 84(4):341

Marinho, C. R.; Azevedo, A. C. G.; Valgode, M. A.; Queiroz, M. M. C. \& Aguiar-Coelho, V. M. 2006. Diversity of Calliphoridae (Diptera) in Reserva Biológica do Tinguá, Nova Iguaçu, Rio de Janeiro. Brazilian Journal of Biology 66(1A):95-100.

Marinho, C. R.; Barbosa, L. S.; Azevedo, A. C. G.; Queiroz, M. M. C.; Valgode, M. A. \& Aguiar-Coelho, V. M. 2003. Hemilucilia segmentaria (Fabricius, 1805) Diptera:Calliphoridae) as New
Biological Vector of Eggs of Dermatobia hominis (Linnaeus Jr., 1781) (Diptera: Oestridae) in Reserva Biológica do Tinguá, Rio de Janeiro, Brazil. Memórias do Instituto Oswaldo Cruz 98(7): $937-938$

Mello, R. P. 1967. Contribuição ao estudo dos mesembrinelídeos Sul-Americanos (Diptera, Calliphoridae). Studia Entomology 10:1-80.

2003. Chave para identificação das formas adultas das espécies da família Calliphoridae (Diptera: Brachycera, Cyclorrhapha) encontradas no Brasil. Entomologia y Vectores 10(2):255-268.

Mello, R. S.; Queiroz, M. M. C.; Aguiar-Coelho, V. M. 2007. Population fluctuations of calliphorid species (Diptera, Calliphoridae) in the Biological Reserve of Tingua, state of Rio de Janeiro, Brazil. Iheringia, Série Zoologia, 97(4):472-480.

Мıнок, S. 2002. The development of a multipurpose trap (the Nzi) for tsetse and other biting flies. Bulletin of Entomological Research 92:385-403.

Monteiro, R. M. 1995. Microhimenópteros (Insecta: Hymenoptera) parasitóides e insetos predadores de moscas sinantrópicas (Insecta: Diptera) na Granja Capuavinha, Monte-Mor, SP. Tese (Mestr.) UNICAMP, Campinas. (Não publicada)

Moura, M. O.; Carvalho, C. J. B. \& Monteiro-Filho, E. L. A. 1997. A preliminary analysis of insects of medico-legal importance in Curitiba, States of Paraná. Memórias do Instituto Oswaldo Cruz 92(2):269-274.

Moya-BorJa, G. E. 2003. Erradicação ou manejo integrado das mí́ases neotropicais das Américas? Pesquisa Veterinária Brasileira 23(3):131-138.

Ndegwa, P. N. \& Мiнок, S. 1999. Development of odour-baited traps fir Glossina swynnertoni (Diptera: Glossinidae). Bulletin of Entomological Research 89:255-261.

Oliveira, V. C.; Mello, R. P. \& D'Almeida, J. M. 2002. Díptero muscóides como vetores mecânicos de ovos de helmintos em jardim zoológico, Brasil. Revista de Saúde Pública 36(5):614-620.

Paraluppi, N. D. \& Castellón, E. G. 1994. Calliphoridae (Diptera) em Manaus: I Levantamento Taxonômico e sazonalidade. Revista Brasileira de Entomologia 38:661-668.

Pichaud, F.; Briscoe, A. \& Desplan, C. 1999. Evolution of color vision. Current Opinion of Neurobiology 9:622-627.

Pickens, L. G.; Jaworski, J.; Kovac, B. \& Mills, G. D. 1994. Traps and baits for flies (Diptera) on Pacific Islands. Annals of Entomological Society of American 31(6):828-832.

Prado, A. P. \& Guimarães, J. H. 1982. Estado atual de dispersão e distribuição do gênero Chrysomya Robineau-Desvoidy na Região neotropical (Diptera, Calliphoridae). Revista Brasileira de Entomologia 26:225-231.

РRокору, R. J. \& OwENs, E. D. 1978. Visual generalist vs visual specialist phytophagous insects: host selection behaviour and aplication to management. Experimental Applied Entomology 24:609-620.

Rocha, C. F. D.; Bergallo, H. G.; Alves, M. A. S. \& Van Sluys, M. 2003. A biodiversidade nos grandes remanescentes florestais do Estado do Rio de Janeiro e nas restingas da Mata Atlântica. São Carlos, Editora RiMa. 160p.

Silva, M. S.; Fontenelle, J. C. R. \& Martins, R. P. 2001. Por que moscas visitam flores? Revista Ciência Hoje 30(175):68-71.

Silveira Neto, S. 1976. Manual de Ecologia dos Insetos. Piracicaba, Ceres. 419p.

Sukontason, K. L.; Narongchai, P.; Sripakdee, D.; Boonchu, N.; Chaiwong, T.; Ngern-Klun, R.; Pianguai, S. \& Sukontason, K. 2005. First Report of Human Myiasis Caused by Chrysomya megacephala and Chrysomya rufifacies (Diptera: Calliphoridae) in Thainland, and Its Implication in Forensic Entomology. Journal of Medical Entomology 42(4):702-704.

Wall, R. \& Sмiтh, K. E. 1996. Colour discrimination by the sheep blowfly Lucilia sericata. Medical and Veterinary Entomology 10:235-240.

ZAR, J. H. 1999. Biostatistical analysis. 4 ed. New Jersey, Prentice-Hall. 663p.

Zumpt, F. 1965. Myiasis in Man and Animal in the Old World. London, Butterworths. 267p 